\title{
Potential daylight resources between tropical and temperate cities - a case study of Ho Chi Minh City and Moscow
}

\author{
Phuong Khanh Thi Nguyen $^{1, *}$, and Aleksei Solovyov ${ }^{1}$ \\ ${ }^{1}$ Moscow State University of Civil Engineering, Yaroslavskoe shosse, 26, Moscow, 129337, Russia
}

\begin{abstract}
Horizontal illuminance is an important indicator, which shows the resources of the light climate of each region. Meticulous consideration of the light-climate data allows us to develop graphs of diffuse and global illuminance $\left(E_{D}\right.$ and $\left.E_{G}\right)$ and go to the territorial norms of daylight spaces at the modern level. Measurements of horizontal illuminance in Vietnam are not available; therefore, the calculation of the determination horizontal illuminance from solar radiation by light equivalents using the values of the luminous efficacy is widely used now. The paper contains calculation of the luminous efficacy for Vietnam, the results are graphs of horizontal illuminance for Ho Chi Minh. Comparative analysis with horizontal natural illuminance of Moscow shows a high level and uniform distribution of outdoor illuminance in the tropical sky in Vietnam. The maximum values of $E_{D}$ and $E_{G}$ for Ho Chi Minh City are 42.01 Klux and 87.17 Klux; for Moscow these values are equal to 28.3 Klux and 53.1 Klux, respectively. In addition, the levels of illuminance in the winter months in Ho Chi Minh are much higher than in Moscow, which is explained by the latitudinal difference in the location of these cities and the corresponding movement of the Sun.
\end{abstract}

\section{Introduction}

The horizontal illuminance is an important indicator that shows the resources of the light climate of each region. To characterize the daylight in a room, the Daylight Factor (DF) is used. Daylight Factor is defined as the ratio of the internal illuminance at a workplane point in the building to the unshaded, external horizontal illuminance under a CIE overcast sky. DF is well defined and simple to calculate. However, it does not account for orientation, shading and glare control, or change in sky conditions. DF can give a general report of the average daylight conditions in a space, but cases of exceedingly high illuminance cannot be addressed.

In the tropical climatic conditions of Vietnam, the overcast sky is not typically considered. Global illuminance and direct sunlight greatly affect daylight availability in indoor environments. Consequently, light shelves and sunshading devices are often used to help reducing glare issues, providing better illuminance distribution into the spaces as direct sunlight gives more reflected light into the room. Therefore, to assess the energy efficiency

* Corresponding author: phuongntk@nuce.edu.vn 
of daylighting systems in buildings in a tropical climate, it is necessary to study the light climate with the global and diffuse horizontal illuminance.

Until now, measured external diffuse illuminance data is not available in Vietnam, approaches are needed to estimate horizontal diffuse and global illuminance based on more widely available diffuse irradiance data. Toward this end, the notion of diffuse luminous efficacy is typically applied, which denotes the ratio of diffuse illuminance to diffuse irradiance $\left(\mathrm{K}_{\mathrm{D}}\right)$, global illuminance to global irradiance $\left(\mathrm{K}_{\mathrm{G}}\right)$.

In this paper, the calculated values of diffuse and global horizontal illuminance for Ho Chi Minh city are determined, an analysis compared to Moscow is held. With the help of the computer program Matlab a mathematical model has been created to describe surfaces of diffuse and global horizontal illuminance.

\section{Methodology}

Some models for determining luminous efficacy have been developed for different states of the sky. Luminous efficacy of solar radiation depends on the solar altitude during sunny states. Direct sunlight luminous efficacy increases in accordance with the solar altitude with a higher increment in the lower values and a lower increment in higher values. Global and diffuse luminous efficacies are rather independent from solar altitude while values of diffuse luminous efficacy are higher than values of global luminous ones $[1,2]$. The luminous efficacy is often derived from three basic parameter groups [3]:

The first group (Littlefair model): take into account only the solar altitude $\left(\gamma_{\mathrm{s}}\right)$, Littlefair offers two formulae for estimating direct luminous efficacy equation (1) and global luminous efficacy equation (2). Diffuse luminous efficacy can be defined as the difference $\mathrm{E}_{\mathrm{ffd}}=\mathrm{E}_{\mathrm{ffg}}-\mathrm{E}_{\mathrm{ffs}}$.

$$
\begin{aligned}
& \mathrm{E}_{\mathrm{ffs}}=51.8+1.646 \gamma_{\mathrm{s}}-0.01513 \gamma_{\mathrm{s}} \\
& \mathrm{E}_{\mathrm{ffg}}=104.4+0.18 \gamma_{\mathrm{s}}-0.0009 \gamma_{\mathrm{s}}
\end{aligned}
$$

The second group (Perez model): several meteorological variables are used to design luminous efficacy for all types of sky. This luminous efficacy model is based on parameters: sky clearness $(\varepsilon)$, solar zenith angle $(Z)$, atmospheric condensation of water vapor $(W)$, and sky brightness $(\Delta)$.

$$
\mathrm{K}_{\mathrm{D}}=\mathrm{a}_{\mathrm{i}}+\mathrm{b}_{\mathrm{i}} \mathrm{W}+\mathrm{c}_{\mathrm{i}} \cos \mathrm{Z}+\mathrm{d}_{\mathrm{i}} \ln (\Delta)
$$

The third group (mean diffuse luminous efficacy): based on the database of measured diffuse horizontal irradiance $\left(\mathrm{Q}_{\mathrm{D}}\right)$ and illuminance $\left(\mathrm{E}_{\mathrm{D}}\right)$ levels, a local constant values $\mathrm{K}_{\mathrm{D}}$ for the diffuse luminous efficacy was derived as follows [3,4]. Similarly, the local constant value of the total light efficiency $\mathrm{K}_{\mathrm{G}}$ is determined by the formula:

$$
K_{D}=\frac{\mathrm{E}_{D}}{Q_{D}} \text { and } K_{G}=\frac{\mathrm{E}_{G}}{Q_{G}}
$$

\subsection{Review of light climate studies}

According to the study of authors A. Zain-Ahmed et al. [5] (Malaysia) in 2002, the General Exterior Illuminance Prediction Model [6] was selected and used to estimate the horizontal illuminance in Malaysia. Values of luminous efficacy for diffuse and global illuminance, respectively, $\mathrm{K}_{\mathrm{D}}=120 \mathrm{Lm} / \mathrm{W}, \mathrm{K}_{\mathrm{G}}=112 \mathrm{Lm} / \mathrm{W}$ for Shubang $\left(3.06^{0}\right.$ northern latitude). The maximum values of the global horizontal illuminance exceed 80,000 lux and 60,000 lux in the spring and winter months (March and December). The value of $\mathrm{K}_{\mathrm{G}}$ was equal to $133 \pm$ $2 \% \mathrm{Lm} / \mathrm{W}$ for Bangi $\left(4.34^{\circ}\right.$ northern latitude), respectively the global horizontal illuminance 
$E_{G}$ is exceeded 140000 lux. For Shah Alam city (3.070 northern latitude) these values are respectively equal to $119 \pm 2 \% \mathrm{Lm} / \mathrm{W}$ and 100000 lux.

It is becoming more important to offer models of luminous efficacy with increasing accuracy for the calculation of horizontal illuminance, as the quality of illuminance data has an important role in the process of building information modeling. Sokol Dervishi and Ardeshire Mahdavi [4] compared and evaluated several models for the calculation of diffuse luminous efficacy based on database of the measured diffuse illuminance and diffuse radiation from the Sun in Vienna (Austria). Seven calculated models of the luminous efficacy were chosen to compare the performance. The results show that all models provide data that is significantly different from the measurements. The simplest model, which is shown by the expression (4), applies only the average (constant) values of the diffuse luminous efficiency of the $\mathrm{K}_{\mathrm{D}}$ gives results much better than other - more detailed models. The model of Perez et al. widely used in the world, shows insufficient accuracy compared to the measurement data.

\subsection{Research method for determining the light climate of Vietnam}

In this study, to determine the light climate of Vietnam were used model authors Nguyen Sanh Dan et al. [7]. It was chosen to determine the daily course of diffuse and global illuminance in cities of Vietnam based on the determination of luminous efficacy at different heights of the Sun.

The height of the Sun in the sky is calculated by the formulas (5) and (6):

$$
\begin{gathered}
\mathrm{h}_{0}=\arcsin \{\sin \delta \cdot \sin \varphi+\cos \delta \cdot \cos \varphi \cdot \cos [150(12-\mathrm{T})]\},\left({ }^{0}\right) \\
\delta=23.45 \sin \left[\frac{360}{365}(\mathrm{~d}-81)\right] \text { and } \delta=23.45 \sin \left[\frac{360}{365}(284+\mathrm{d})\right],\left({ }^{0}\right)
\end{gathered}
$$

where: $\mathrm{d}$ - the serial number of the day in the year, counting from 1 January;

$\mathrm{h}_{0}$ - the height of the sun, $\left(^{0}\right)$;

$\delta$ - declination of the sun on any day of the year, $\left({ }^{0}\right) \mathrm{s}$;

$\mathrm{T}$ - time in hours, for example, $16 \mathrm{~h} 15 \mathrm{~m}=16.25 \mathrm{~h}$;

$\varphi$ - latitude (South - minus sign), $\left({ }^{0}\right)$.

The luminous efficacy of solar radiation is calculated according to the formula (7):

$$
\begin{aligned}
& \mathrm{K}_{\mathrm{D}}=0 \cdot 1 \cdot \mathrm{h}_{0}+67,\left(\mathrm{Klux} / \mathrm{kcal} \cdot \mathrm{cm}^{-2} \cdot \mathrm{min}^{-1}\right) \\
& \mathrm{K}_{\mathrm{G}}=0.1 \cdot \mathrm{h}_{0}+62,\left(\mathrm{Klux} / \mathrm{kcal} \cdot \mathrm{cm}^{-2} \cdot \mathrm{min}^{-1}\right) .
\end{aligned}
$$

Values of diffuse and global illuminance are obtained by multiplying data on solar diffuse radiation for $\mathrm{K}_{\mathrm{D}}$ and data on solar global radiation for $\mathrm{K}_{\mathrm{G}}$. That is logically the expressions (4).

Data on solar radiation are selected from ASHRAE IWEC2 files - «Weather data for energy calculations», which were developed for ASHRAE by White Box Technologies, Inc. and are based on the integrated hourly basis over the ISD surface for 3012 locations outside the US and Canada that have a minimum of 12 years of recording up to 25 years. When converting the raw Integrated surface Hourly Database (ISD) into local time, the software fills or reduces data before hourly time steps and calculates solar radiation. Data on the weather of the light climate of Ho Chi Minh city were obtained within twelve years, from 2005 to the end of 2017 and are typical data. The choice of these typical months is based not only on the average but also on statistical distributions of different climatic parameters by months, which were collected from the records of long-term observations [8].

\subsection{Research plan}

Figure 1 shows the scheme of the research plan, which was developed to determine the value of luminous efficacy in accordance with the model [7]. It is selected for the calculation of the daily course of diffuse and global illuminance in Ho Chi Minh city (Vietnam) and Moscow (Russia). 


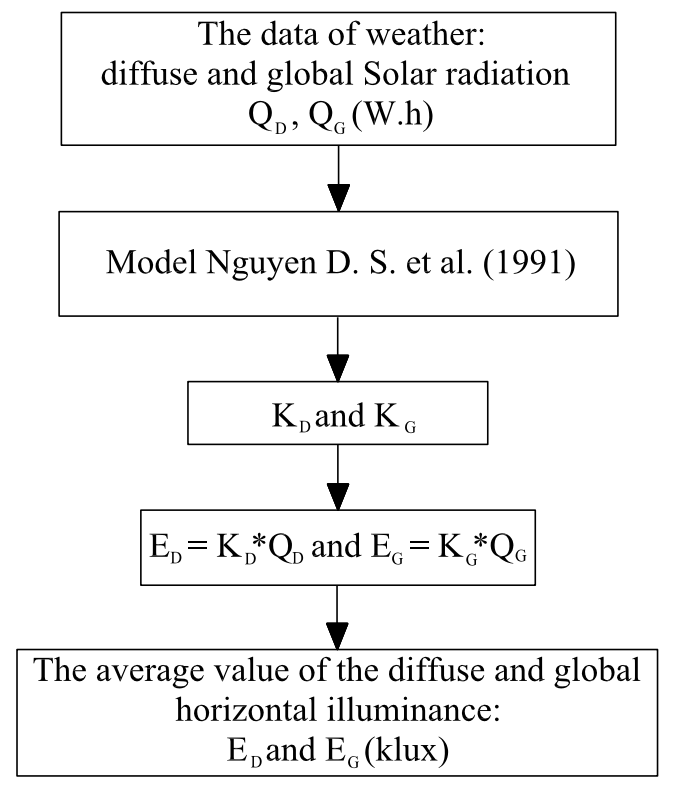

Fig. 1. Research plan

\section{Results and discussion}

According to this model calculation, the values of the luminous efficiency of $K_{D}$ and $K_{Q}$ for the Ho Chi Minh city (Vietnam) are respectively 70 and $65\left(\mathrm{Klux} / \mathrm{kcal}_{\mathrm{cm}} \mathrm{cmin}^{-1}\right.$ ) or 101 and $93(\mathrm{~lm} / \mathrm{W})$. The diffuse and global illuminance in Ho Chi Minh city and in Moscow are presented in tables 1 and 2 .

Table 1. Diffuse/global horizontal illuminance for Ho Chi Minh city

\begin{tabular}{|c|c|c|c|c|c|c|c|c|c|c|c|c|c|}
\hline \multirow{2}{*}{\multicolumn{2}{|c|}{\begin{tabular}{|c|} 
Months \\
Sunrise time
\end{tabular}}} & I & II & III & IV & V & VI & VII & VIII & IX & $X$ & XI & XII \\
\hline & & $6 \mathrm{~h} 16$ & $6 \mathrm{~h} 14$ & $6 \mathrm{~h} 01$ & $5 \mathrm{~h} 43$ & $5 \mathrm{~h} 31$ & $5 \mathrm{~h} 31$ & $5 \mathrm{~h} 38$ & $5 \mathrm{~h} 43$ & $5 \mathrm{~h} 43$ & $5 \mathrm{~h} 46$ & $5 \mathrm{~h} 49$ & $6 \mathrm{~h} 03$ \\
\hline \multirow{15}{*}{$\begin{array}{l}\text { Hours } \\
\text { of day } \\
\text { (hours) }\end{array}$} & 6 & & & & $\begin{array}{c}0.2 / \\
0.2\end{array}$ & $\begin{array}{c}0.8 / \\
0.9\end{array}$ & $\begin{array}{l}0.8 / \\
0.9\end{array}$ & $\begin{array}{l}0.3 / \\
0.4\end{array}$ & $\begin{array}{l}0.1 / \\
0.1\end{array}$ & $\begin{array}{l}0.1 / \\
0.2\end{array}$ & $\begin{array}{l}0.1 / \\
0.2\end{array}$ & $\begin{array}{l}0 / \\
0\end{array}$ & \\
\hline & 7 & $\begin{array}{l}1.8 / \\
2.4\end{array}$ & $\begin{array}{l}1.6 / \\
2.8\end{array}$ & $\begin{array}{l}4.0 / \\
5.0\end{array}$ & $\begin{array}{l}6.4 / \\
8.8\end{array}$ & $\begin{array}{l}7.9 / \\
10.8\end{array}$ & $\begin{array}{c}7.4 / \\
10.2\end{array}$ & $\begin{array}{l}6.2 / \\
8.1\end{array}$ & $\begin{array}{l}6.0 / \\
7.7\end{array}$ & $\begin{array}{l}6.1 / \\
7.7\end{array}$ & $\begin{array}{l}6.3 / \\
8.0\end{array}$ & $\begin{array}{l}5.2 / \\
6.6\end{array}$ & $\begin{array}{l}3.1 / \\
4.0\end{array}$ \\
\hline & 8 & $\begin{array}{l}9.8 / \\
15.7\end{array}$ & $\begin{array}{l}11.4 / \\
18.7\end{array}$ & $\begin{array}{l}14.0 / \\
22.4\end{array}$ & $\begin{array}{l}15.8 / \\
27.6\end{array}$ & $\begin{array}{l}17.3 / \\
28.1\end{array}$ & $\begin{array}{l}16.6 / \\
26.7\end{array}$ & $\begin{array}{l}15.9 / \\
23.4\end{array}$ & $\begin{array}{l}15.9 / \\
23.8\end{array}$ & $\begin{array}{l}16.1 / \\
23.7\end{array}$ & $\begin{array}{l}16.9 / \\
23.8\end{array}$ & $\begin{array}{l}14.5 / \\
21.7\end{array}$ & $\begin{array}{l}11.8 / \\
17.8\end{array}$ \\
\hline & 9 & $\begin{array}{c}18.61 / \\
32.8\end{array}$ & $\begin{array}{l}19.6 / \\
39.2\end{array}$ & $\begin{array}{l}22.8 / \\
43.0\end{array}$ & $\begin{array}{l}23.7 / \\
47.8\end{array}$ & $\begin{array}{l}26.1 / \\
46.0\end{array}$ & $\begin{array}{l}25.4 / \\
43.7\end{array}$ & $\begin{array}{l}25.6 / \\
39.8\end{array}$ & $\begin{array}{l}25.4 / \\
41.2\end{array}$ & $\begin{array}{l}26.1 / \\
40.6\end{array}$ & $\begin{array}{l}26.8 / \\
40.2\end{array}$ & $\begin{array}{l}23.3 / \\
37.7\end{array}$ & $\begin{array}{l}20.6 / \\
33.6\end{array}$ \\
\hline & 10 & $26.1 /$ & & $29.3 /$ & $29.6 /$ & $32.1 /$ & $32.4 /$ & $33.7 /$ & 33.81 & $34.6 /$ & $34.6 /$ & $31.3 /$ & $27.9 /$ \\
\hline & & 48.6 & & 61.9 & 65.9 & 61.7 & 58.9 & 54.5 & 56.8 & 55.5 & 54.3 & 51.4 & 47.5 \\
\hline & 11 & $\begin{array}{l}31.2 / \\
60.5\end{array}$ & $\begin{array}{c}29.2 / \\
73.1\end{array}$ & $\begin{array}{c}33.0 / \\
76.4\end{array}$ & $\begin{array}{c}33.2 / \\
79.6\end{array}$ & $\begin{array}{l}35.8 / \\
73.4\end{array}$ & $\begin{array}{c}36.2 / \\
70.2\end{array}$ & $\begin{array}{r}38.0 / \\
65.8\end{array}$ & $\begin{array}{l}38.9 / \\
68.9\end{array}$ & $\begin{array}{l}40.5 / \\
66.6\end{array}$ & $\begin{array}{c}39.6 / \\
64.2\end{array}$ & $\begin{array}{c}35.4 / \\
60.9\end{array}$ & $\begin{array}{l}33.0 / \\
575\end{array}$ \\
\hline & 12 & $34.0 /$ & $30.5 /$ & $34.7 /$ & $35.1 /$ & $38.2 /$ & $38.2 /$ & $40.6 /$ & $41.4 /$ & $41.7 /$ & $42.0 /$ & $37.6 /$ & $35.0 /$ \\
\hline & & 66.9 & 81.4 & 84.4 & 87.2 & 79.4 & 76.0 & 71.9 & 75.7 & 72.1 & 68.4 & 64.8 & 62.2 \\
\hline & 13 & $\begin{array}{l}34.5 / \\
66.8\end{array}$ & $\begin{array}{l}30.5 / \\
81.7\end{array}$ & $\begin{array}{l}34.6 / \\
83.8\end{array}$ & $\begin{array}{l}35.0 / \\
84.9\end{array}$ & $\begin{array}{l}38.3 / \\
77.4\end{array}$ & $\begin{array}{l}37.8 / \\
74.7\end{array}$ & $\begin{array}{l}40.0 / \\
71.0\end{array}$ & $\begin{array}{l}41.1 / \\
74.1\end{array}$ & $\begin{array}{l}41.2 / \\
70.1\end{array}$ & $\begin{array}{l}39.3 / \\
65.9\end{array}$ & $\begin{array}{l}37.1 / \\
62.4\end{array}$ & $\begin{array}{l}34.2 / \\
60.9\end{array}$ \\
\hline & 14 & $\begin{array}{l}31.3 / \\
60.4\end{array}$ & $\begin{array}{l}29.1 / \\
74.4\end{array}$ & $\begin{array}{l}32.6 / \\
75.7\end{array}$ & $\begin{array}{l}33.2 / \\
75.8\end{array}$ & $\begin{array}{l}34.6 / \\
69.1\end{array}$ & $\begin{array}{c}34.0 / \\
67.3\end{array}$ & $\begin{array}{l}36.6 / \\
64.3\end{array}$ & $\begin{array}{l}37.6 / \\
66.6\end{array}$ & $\begin{array}{l}37.0 / \\
62.0\end{array}$ & $\begin{array}{l}35.5 / \\
57.5\end{array}$ & $\begin{array}{l}33.1 / \\
54.2\end{array}$ & $\begin{array}{l}31.2 / \\
53.9\end{array}$ \\
\hline & 15 & $\begin{array}{l}26.1 / \\
48.8\end{array}$ & $\begin{array}{l}26.1 / \\
60.9\end{array}$ & $\begin{array}{r}28.8 / \\
61.6\end{array}$ & $\begin{array}{l}29.0 / \\
61.2\end{array}$ & $\begin{array}{c}28.8 / \\
56.0\end{array}$ & $29.1 /$ & $\begin{array}{l}32.2 / \\
53.0\end{array}$ & $\begin{array}{l}32.1 / \\
54.4\end{array}$ & $\begin{array}{l}31.3 / \\
49.4\end{array}$ & $\begin{array}{l}28.6 / \\
44.6\end{array}$ & $\begin{array}{l}26.7 / \\
41.6\end{array}$ & $\begin{array}{l}25.3 / \\
42.1\end{array}$ \\
\hline & & $19.0 /$ & $20.7 /$ & $22.8 /$ & $22.7 /$ & $21.8 /$ & $22.7 /$ & 24.2 & $24.4 /$ & $22.1 /$ & $19.0 /$ & $17.2 /$ & $17.3 /$ \\
\hline & 10 & 33.5 & 42.9 & 43.2 & 42.8 & 39.5 & 39.6 & 38.5 & 38.8 & 33.6 & 28.7 & 26.0 & 27.3 \\
\hline & 17 & $10.3 /$ & $13.2 /$ & $13.9 /$ & $14.2 /$ & $13.0 /$ & $13.9 /$ & $15.2 /$ & $14.2 /$ & $11.6 /$ & $8.9 /$ & $7.2 /$ & $8.2 /$ \\
\hline
\end{tabular}




\begin{tabular}{|c|c|c|c|c|c|c|c|c|c|c|c|c|c|}
\hline & & 16.6 & 22.8 & 23.1 & 22.9 & 21.7 & 22.7 & 22.4 & 21.7 & 16.8 & 12.4 & 10.2 & 11.8 \\
\cline { 2 - 12 } & \multirow{2}{*}{18} & $1.8 /$ & $4.1 /$ & $4.4 /$ & $4.5 /$ & $4.2 /$ & $5.2 /$ & $5.6 /$ & $4.7 /$ & $2.4 /$ & $1.3 /$ & $0.7 /$ & $1.2 /$ \\
& 3.0 & 5.4 & 5.6 & 5.6 & 6.0 & 7.2 & 7.5 & 6.3 & 3.2 & 1.5 & 0.8 & 1.4 \\
\cline { 2 - 12 } & & & & & & $0.1 /$ & $0.2 /$ & $0 /$ & & & & \\
& \multirow{2}{*}{19} & & & & & & 0.1 & 0.2 & 0 & & & & \\
& & & & & & & & & & \\
\hline
\end{tabular}

Table 2. Diffuse/global horizontal Illuminance for Moscow [9]

\begin{tabular}{|c|c|c|c|c|c|c|c|c|c|c|c|c|c|}
\hline \multirow{2}{*}{\multicolumn{2}{|c|}{\begin{tabular}{|c|} 
Months \\
Sunrise time \\
\end{tabular}}} & I & II & III & IV & $\mathrm{V}$ & VI & VII & VIII & IX & $\mathrm{X}$ & XI & XII \\
\hline & & $8 \mathrm{~h} 21$ & $7 \mathrm{~h} 28$ & $6 \mathrm{~h} 17$ & $4 \mathrm{~h} 57$ & $3 \mathrm{~h} 50$ & $3 \mathrm{~h} 15$ & $3 \mathrm{~h} 35$ & $4 \mathrm{~h} 30$ & $5 \mathrm{~h} 30$ & $6 \mathrm{~h} 29$ & $7 \mathrm{~h} 35$ & $8 \mathrm{~h} 23$ \\
\hline \multirow{22}{*}{$\begin{array}{c}\text { Hours of } \\
\text { days } \\
\text { (hours) }\end{array}$} & 3 & & & & & $\begin{array}{l}-2.5 / \\
-6.0\end{array}$ & $\begin{array}{l}-0.8 / \\
-1.9\end{array}$ & $\begin{array}{l}-1.1 / \\
-2.8\end{array}$ & & & & & \\
\hline & 4 & & & & & $\begin{array}{c}0.5 / \\
1.2 \\
\end{array}$ & $\begin{array}{c}2.4 / \\
5.6\end{array}$ & $\begin{array}{l}1.1 / \\
2.8\end{array}$ & $\begin{array}{c}-1.8 / \\
0\end{array}$ & & & & \\
\hline & 5 & & & & $\begin{array}{l}0 / \\
0\end{array}$ & $\begin{array}{c}3.7 / \\
9.1\end{array}$ & $\begin{array}{l}5.5 / \\
12.6\end{array}$ & $\begin{array}{l}4.4 / \\
9.1\end{array}$ & $\begin{array}{l}1.8 / \\
-3.5 \\
\end{array}$ & $\begin{array}{l}-1.8 / \\
-3.1\end{array}$ & & & \\
\hline & 6 & & & $\begin{array}{l}-0.8 / \\
-1.9 \\
\end{array}$ & $\begin{array}{l}3.6 / \\
8.4 \\
\end{array}$ & $\begin{array}{l}6.9 / \\
17.0 \\
\end{array}$ & $\begin{array}{l}8.5 / \\
19.6 \\
\end{array}$ & $\begin{array}{l}7.7 / \\
15.4 \\
\end{array}$ & $\begin{array}{l}5.4 / \\
10.6 \\
\end{array}$ & $\begin{array}{l}1.8 / \\
3.1\end{array}$ & $\begin{array}{l}-1.1 / \\
-2.1 \\
\end{array}$ & & \\
\hline & 7 & & $\begin{array}{l}-1.6 / \\
-2.5\end{array}$ & $\begin{array}{l}2.6 / \\
5.7\end{array}$ & $\begin{array}{l}6.9 / \\
16.4\end{array}$ & $\begin{array}{l}10.2 / \\
24.9\end{array}$ & $\begin{array}{l}11.7 / \\
26.8\end{array}$ & $\begin{array}{l}11.5 / \\
22.0\end{array}$ & $\begin{array}{l}8.8 / \\
17.9\end{array}$ & $\begin{array}{l}5.8 / \\
9.1\end{array}$ & $\begin{array}{l}1.1 / \\
2.1\end{array}$ & $\begin{array}{l}-0.6 / \\
-1.1\end{array}$ & \\
\hline & 8 & $\begin{array}{l}-0.7 / \\
-1.0\end{array}$ & $\begin{array}{l}1.6 / \\
2.5\end{array}$ & $\begin{array}{l}5.9 / \\
13.2\end{array}$ & $\begin{array}{l}10.1 / \\
24.4\end{array}$ & $\begin{array}{l}13.4 / \\
32.8\end{array}$ & $\begin{array}{l}14.8 / \\
33.9\end{array}$ & $\begin{array}{l}15.3 / \\
28.6\end{array}$ & $\begin{array}{l}12.2 / \\
25.2\end{array}$ & $\begin{array}{l}9.8 / \\
15.1\end{array}$ & $\begin{array}{l}3.4 / \\
6.2\end{array}$ & $\begin{array}{l}0.6 / \\
1.1\end{array}$ & $\begin{array}{l}-0.4 / \\
-0.8\end{array}$ \\
\hline & 9 & $1.4 /$ & $4.9 /$ & $9.5 /$ & $13.6 /$ & $16.7 /$ & 18.0/ & $19.2 /$ & $15.7 /$ & $13.7 /$ & $5.8 /$ & $2.4 /$ & $0.9 /$ \\
\hline & 10 & $3.4 /$ & $8.2 /$ & $13.0 /$ & $17.0 /$ & $19.9 /$ & $21.2 /$ & $23.0 /$ & $19.1 /$ & $17.5 /$ & $8.1 /$ & 4.21 & $2.1 /$ \\
\hline & 10 & 5.0 & 12.5 & 28.8 & 40.0 & 47.9 & 46.4 & 42.0 & 37.5 & 26.2 & 14.0 & 6.0 & 3.8 \\
\hline & 11 & $\begin{array}{l}5.2 / \\
7.1\end{array}$ & $\begin{array}{l}10.4 / \\
16.5\end{array}$ & $\begin{array}{l}15.3 / \\
31.8\end{array}$ & $\begin{array}{l}19.1 / \\
42.8\end{array}$ & $\begin{array}{l}21.6 / \\
50.5\end{array}$ & $\begin{array}{l}23.5 / \\
47.5\end{array}$ & $\begin{array}{l}25.7 / \\
44.9\end{array}$ & $\begin{array}{l}21.7 / \\
38.5\end{array}$ & $\begin{array}{l}18.9 / \\
28.2\end{array}$ & $\begin{array}{l}9.6 / \\
15.9\end{array}$ & $\begin{array}{l}5.6 / \\
7.4\end{array}$ & $\begin{array}{c}2.9 / \\
5.2\end{array}$ \\
\hline & 12 & $7.0 /$ & $12.5 /$ & $17.6 /$ & $21.1 /$ & $23.2 /$ & $25.7 /$ & $28.3 /$ & $24.2 /$ & $20.2 /$ & $11.1 /$ & $7.0 /$ & $3.7 /$ \\
\hline & 13 & $6.0 /$ & $11.6 /$ & $16.4 /$ & $19.9 /$ & $22.5 /$ & $24.3 /$ & $26.5 /$ & $23.0 /$ & $18.3 /$ & $10.3 /$ & $5.8 /$ & $3.0 /$ \\
\hline & 13 & 7.4 & 17.2 & 31.9 & 41.2 & 48.9 & 46.9 & 46.0 & 37.9 & 27.2 & 15.2 & 6.9 & 5.4 \\
\hline & 14 & $\begin{array}{l}5.0 / \\
5.6\end{array}$ & $\begin{array}{l}10.7 / \\
140\end{array}$ & $\begin{array}{l}15.2 / \\
290\end{array}$ & $\begin{array}{l}18.7 / \\
368\end{array}$ & $\begin{array}{l}21.8 / \\
446\end{array}$ & $22.8 /$ & $\begin{array}{l}24.6 / \\
442\end{array}$ & $21.8 /$ & $16.4 /$ & $\begin{array}{l}9.4 / \\
127\end{array}$ & $4.5 /$ & $2.3 /$ \\
\hline & 15 & $2.5 /$ & $7.3 /$ & $12.0 /$ & $16.0 /$ & $19.0 /$ & $20.2 /$ & $21.3 /$ & $19.1 /$ & $12.7 /$ & $6.7 /$ & $2.3 /$ & $0.8 /$ \\
\hline & 15 & 2.8 & 9.3 & 22.0 & 29.6 & 36.8 & 39.1 & 38.5 & 30.8 & 18.2 & 8.5 & 2.5 & 1.4 \\
\hline & 16 & $\begin{array}{c}0 / \\
0\end{array}$ & $\begin{array}{l}3.9 / \\
4.5\end{array}$ & $\begin{array}{l}8.7 / \\
14.9\end{array}$ & $\begin{array}{l}13.2 / \\
22.3\end{array}$ & $\begin{array}{l}16.2 / \\
29.0\end{array}$ & $\begin{array}{l}17.5 / \\
32.9\end{array}$ & $\begin{array}{l}17.9 / \\
32.7\end{array}$ & $\begin{array}{l}16.3 / \\
25.4\end{array}$ & $\begin{array}{l}9.0 / \\
12.3\end{array}$ & $\begin{array}{l}3.9 / \\
4.2\end{array}$ & $\begin{array}{c}0 / \\
0\end{array}$ & $\begin{array}{l}-0.8 / \\
-1.4\end{array}$ \\
\hline & 17 & & $\begin{array}{c}0 / \\
0\end{array}$ & $\begin{array}{l}4.4 / \\
7.5\end{array}$ & $\begin{array}{l}8.9 / \\
15.2\end{array}$ & $\begin{array}{l}12.3 / \\
21.8\end{array}$ & $\begin{array}{l}14.1 / \\
260\end{array}$ & $\begin{array}{l}14.4 / \\
25.7\end{array}$ & $\begin{array}{l}11.9 / \\
186\end{array}$ & $5.3 /$ & $\begin{array}{l}0 / \\
0\end{array}$ & & \\
\hline & 18 & & & $\begin{array}{l}0 / \\
0\end{array}$ & $\begin{array}{l}4.6 / \\
8.0\end{array}$ & $\begin{array}{l}8.3 / \\
14.6\end{array}$ & $\begin{array}{l}10.6 / \\
19.1\end{array}$ & $\begin{array}{l}10.8 / \\
18.6\end{array}$ & $\begin{array}{l}7.4 / \\
11.8\end{array}$ & $\begin{array}{l}1.6 / \\
1.8\end{array}$ & & & \\
\hline & 19 & & & & $\begin{array}{c}0 / \\
0\end{array}$ & $\begin{array}{l}4.2 / \\
7.3\end{array}$ & $\begin{array}{l}6.9 / \\
12.0\end{array}$ & $\begin{array}{l}6.7 / \\
11.5\end{array}$ & $\begin{array}{l}1.1 / \\
1.7\end{array}$ & $\begin{array}{l}-3.2 / \\
-3.6\end{array}$ & & & \\
\hline & 20 & & & & & $\begin{array}{c}0 / \\
0\end{array}$ & $\begin{array}{l}3.2 / \\
4.8\end{array}$ & $\begin{array}{l}2.6 / \\
4.4\end{array}$ & $\begin{array}{l}-5.3 / \\
-8.4\end{array}$ & & & & \\
\hline & 21 & & & & & & $\begin{array}{l}-1.3 / \\
-1.6\end{array}$ & $\begin{array}{l}-2.6 / \\
-4.4\end{array}$ & & & & & \\
\hline \multicolumn{2}{|c|}{ Sunset time } & $15 \mathrm{~h} 57$ & $17 \mathrm{~h} 00$ & $18 \mathrm{~h} 01$ & 19h02 & $20 \mathrm{~h} 02$ & $20 \mathrm{~h} 45$ & $20 \mathrm{~h} 37$ & 19h10 & $18 \mathrm{~h} 20$ & $17 \mathrm{~h} 03$ & $15 \mathrm{~h} 53$ & $17 \mathrm{~h} 27$ \\
\hline
\end{tabular}

The computer program Matlab was used to obtain response surface image and corresponding contour plot of the surface of horizontal illuminance in Ho Chi Minh and Moscow, as well as to determine the maximum value of the diffuse/global horizontal surface for these cities, are shown in Figures 2 - 5. 

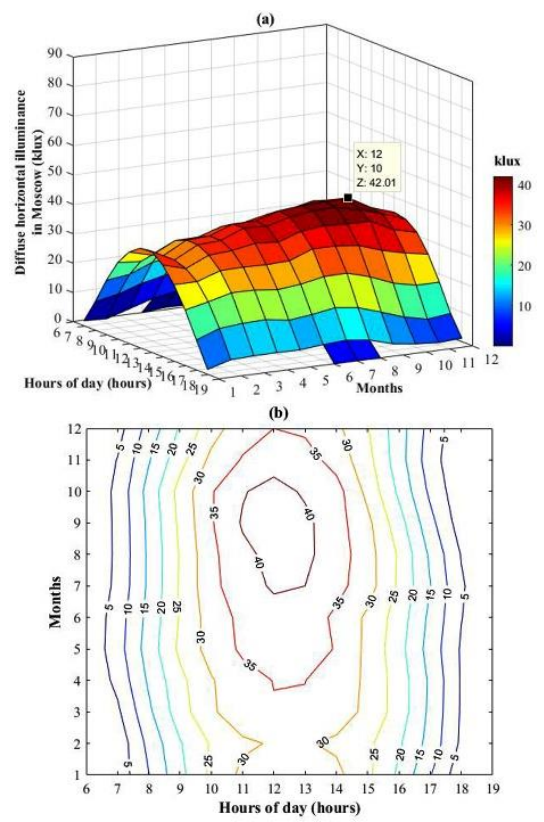

Fig. 2. The response surface and its maximum value (a); contour plot (b) of the diffuse horizontal illuminance in Ho Chi Minh city
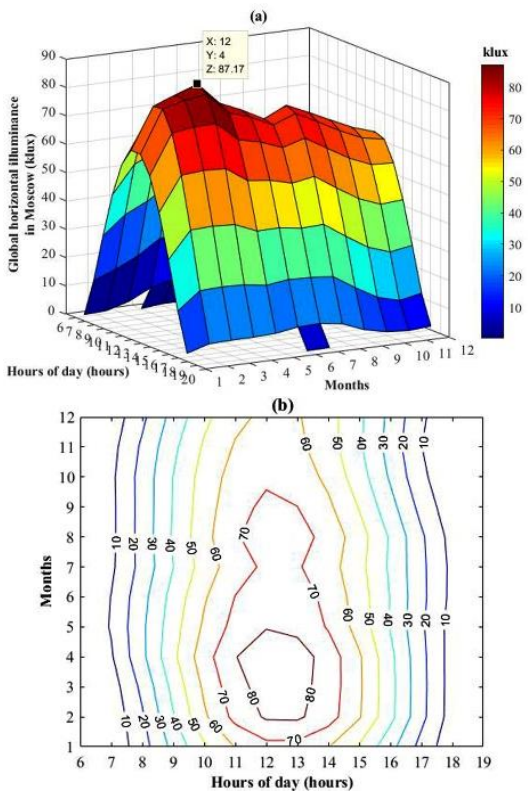

Fig. 4. The response surface and its maximum value (a); contour plot (b) of the global horizontal illuminance in Ho Chi Minh city
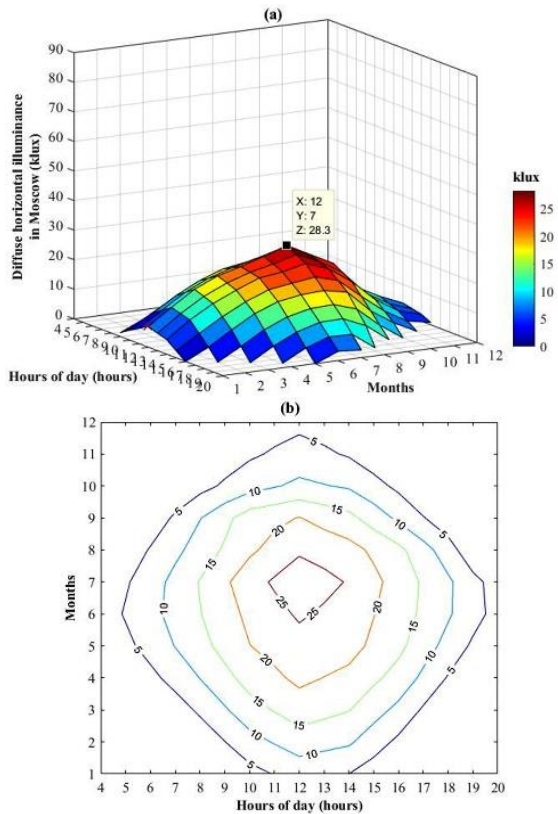

Fig. 3. The response surface and its maximum value (a); contour plot (b) of the diffuse horizontal illuminance in Moscow city
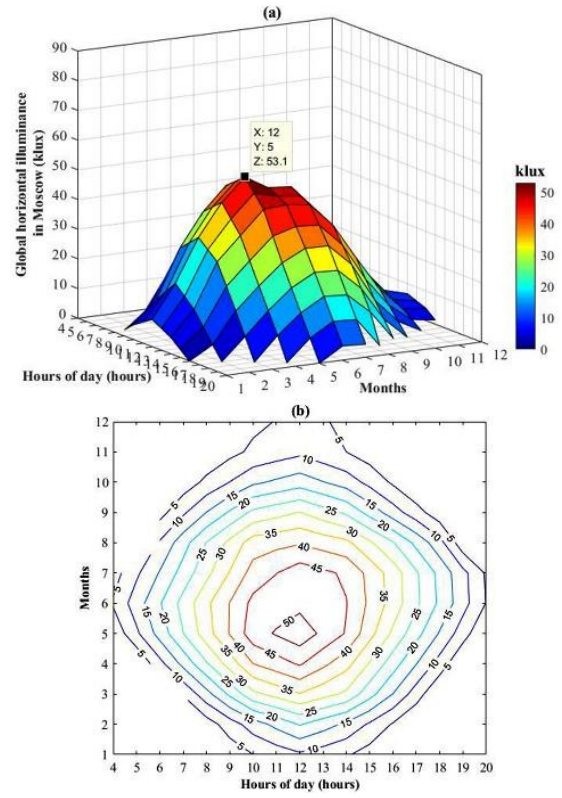

Fig. 5. The response surface and its maximum value (a); contour plot (b) of the global horizontal illuminance in Moscow city

In comparison horizontal illuminance of Ho Chi Minh city $\left(10.82^{0}\right.$ northern latitude $)$ to Moscow $\left(55.75^{\circ}\right.$ northern latitude), it is seen that diffuse and global horizontal illuminance in Ho Chi Minh city varies slightly between months. 
Maximum and minimum level of diffuse horizontal illuminance in Ho Chi Minh city is in September and February. At noon, when peak illuminances are at the highest - 42.01 Klux in September and when peak illuminances are at the lowest - 30.5 Klux in February. These values for the global horizontal illuminance correspond to 87.17 Klux in April and 62.2 Klux in December. For Moscow, maximum and minimum level of diffuse and global horizontal illuminance is in June and December. The highest level of peak diffuse horizontal illuminances at noon is 28.3 Klux in June and the lowest level - 3.7 Klux in December. These values for the global horizontal illuminance are 53.1 Klux and 6.6 Klux correspond to the same period. Diagrams in Figures $2 \mathrm{~b}-5 \mathrm{~b}$ shows the maximum horizontal illuminance in Moscow distributed in the summer months, from May to August. In Ho Chi Minh city, the distribution of the maximum level for global illuminance from February to May, for diffuse illuminance from July to October. The difference period distribution of the maximum level global and diffuse illuminance in Ho Chi Minh city can be shown by unregulated statistics of cloud cover under the Sunny sky of the tropical climate of Vietnam.

The study of daylight resources is very important to determine design strategy in terms of energy efficiency for the buildings. High level of daylight resources in Ho Chi Minh city with homogeneity distribution by months allows using daylighting for spaces all year round. Tropical climatic characteristics with high levels of solar radiation give a large thermal load on the building envelope. Therefore, daylighting systems with sunshading devices are widely used to reduce heat gain from the sun in summer. Sunshading devices reduce daylight illuminance by reducing direct light from the sky. At the same time, sunshading devices play the role of reflective panels, increases reflected light in rooms when direct sunlight hits these reflective panels. The work of graduate student Salo Mohamed Ali [10] in NIU MGSU shows the impact of sunshading devices over Daylight Factor (DF): under clear sky with a partial cloudiness up to 2 points, the average DF in a room with side windows is $3.87 \%$, this value above the average of DF in the cloudy sky $-2.89 \%$. This suggests that, under the condition of direct sunlight in tropical climate, daylight systems with sunshading devices are more effective. In order to assess the energy efficiency of such systems, it is necessary to investigate direct solar irradiation on facades at different orientations and to analyze the effect of different types of sunshading devices.

\section{Conclusion}

According to the calculation results, the following conclusions are drawn:

1. Using model authors Nguyen Sanh Dan and et., the average values of diffuse and global luminous efficacy in Ho Chi Minh city (Vietnam) were calculated respectively 101 and $93(\mathrm{Lm} / \mathrm{W})$.

2. The maximum values of the diffuse/global horizontal surfaces in Ho Chi Minh City and Moscow, respectively, equal to 42.01 Klux/87.17 Klux and 28.3 Klux/53.1 Klux when peak illuminances are at the highest level, were determined by the computer program Matlab.

3. The study and analysis of weather data in recent years in Vietnam makes it possible to analyze the light climate of the regions and to obtain materials for further studies of daylighting in construction of buildings. By results of analysis horizontal illuminance in Ho Chi Minh city and Moscow, the data of weather were obtained on resources of the light climate. They show a uniform illuminance distribution in Ho Chi Minh city for months, in contrast to the uneven distribution of the illuminance in Moscow.

4. The proposed method allows to calculate the graphics of diffuse and global horizontal illuminance for all cities of Vietnam and accuracy of the daylight coefficients. This makes it possible to consider the daylighting of buildings a promising direction to improve the energy efficiency, especially in tropical climatic conditions of Vietnam, where various types of sunshading devices should be widely used. 


\section{References}

1. R. Kittler, M. Kocifaj, S. Darula, Daylight Science and Daylight Technology, Springer, New York (2012)

2. M. Navvab, M. Karayel, E. Neeman, S. Selkowitz, Analysis of luminous efficacy for daylight calculations, In: Proc. Conf. International Daylight Conference, Long Beach, ASHRAE Publications Sales, Atlanta (1986)

3. M. Fabian, Y. Uetani, S. Darula, Monthly luminous efficacy models and illuminance prediction using ground, Solar Energy, 162 (2018)

4. S. Dervishi, A. Mahdavi, A comparison of luminous efficacy models for the diffuse component of solar radiation (Fourth German - Austrian IBPSA Conference Berlin University of Art, Berlin, 2012)

5. A.Zain-Ahmed, K.Sopian, Z.Zainol Abidin, M.Y.H. Othman, The availability of daylight from tropical skies- a case study of Malaysia, Renewable Energy, 25 (2002)

6. R. Perez, P. Ineichen, R. Seals, Modelling daylight availability and irradiance components from direct and global irradiance, Solar Energy, 44 (1990)

7. N.S.Dan, N.V.Muon, P.N.Dang, P.D.Nguyen, light climate in Vietnam, allowance, Scientific and Technical Publishing House (1991)

8. J. Huang, ASHRAE Research Project 1477-RP Development of 3.012 typical year weather files for international locations. White Box Technologies, Moraga CA, Moraga CA, October 19 (2011)

9. A.K. Solovyov, Physical environment, Association of Construction Universities Publishing House, Moscow (2008)

10. S.M. Ali, Increase efficiency of systems daylighting in industrial buildings in Syria (on the example of food industry enterprises). Dissertation for the degree of candidate of technical sciences. Moscow State University of Civil Engineering, Moscow (2005) 